\title{
Effect of infection with bovine leukemia virus on milk production in Michigan dairy cows
}

\author{
B. Norby, ${ }^{* 1}$ P. C. Bartlett, ${ }^{*}$ T. M. Byrem, $\dagger$ and R. J. Erskine ${ }^{*}$ \\ ${ }^{*}$ Department of Large Animal Clinical Sciences, Michigan State University, East Lansing 48824 \\ †Antel BioSystems Inc., Lansing, MI 48909
}

\begin{abstract}
The objective of this study was to determine the association between individual cow-level milk production and bovine leukemia virus (BLV) infection as measured by milk BLV-ELISA. Dairy Herd Improvement technicians collected milk samples from 10 cows from each of first, second, third, and 4+ parity cows in 105 Holstein herds with $\geq 120$ milking cows. Milk samples were tested for the presence of anti-BLV antibodies by ELISA. Additional data regarding the cows and the herds were collected by farm survey and Dairy Herd Improvement records. A set of mixed-effect models using all cows and only $2+$ parity cows were used to investigate the association between BLV ELISA-corrected optical density and 305-d mature equivalents of individual cows. The BLV milk positivity was associated with decreased 305d mature-equivalent yields, especially among the older cows. Additionally, increasing milk ELISA-corrected optical density was associated with increasing loss of milk production at the cow level. In summary, our results provide evidence that BLV infection is associated with decreased milk production in Michigan dairy cows. Key words: bovine leukemia virus, leukosis, prevalence, milk production, dairy cow
\end{abstract}

\section{INTRODUCTION}

Enzootic bovine leukosis is a chronic infectious disease of cattle caused by bovine leukemia virus (BLV), a deltaretrovirus (OIE, 2012). The main route of BLV transmission among cattle appears to be hematogenous transfer of infected B cells, which then allows the virus to infect B cells in the new host. Within a few weeks, the newly infected animal mounts a strong immune response that limits infection of other $\mathrm{B}$ cells, causing the virus to become latent and proliferate only by $\mathrm{B}$ cell mitosis. A persistent lymphocytosis (PL) pheno-

Received July 9, 2015.

Accepted November 7, 2015.

${ }^{1}$ Corresponding author: norby@cvm.msu.edu typic state is observed in approximately $30 \%$ of infected cattle (Kabeya et al., 2001). Cattle that do not become PL remain aleukemic (AL) with normal lymphocyte counts. Those that become PL cattle have a polyclonal expansion of peripheral B cells $(>10,000 / \mu \mathrm{L})$. The proviral load also increases in PL cows, likely making them more infectious to their herdmates (Juliarena et al., 2007; Esteban et al., 2009). Infections with BLV are generally subclinical (OIE, 2012); however, 0.1 to $10 \%$ of BLV-infected cows progress to develop lymphoma (Kabeya et al., 2001). Bovine leukemia virus has been eradicated in 16 Western European countries (Batho et al., 2008), but the animal-level and herd-level prevalences remain high other places in the world. In 1996, the animal-level prevalence in the United States ranged from 39.6 to $68.7 \%$ depending on the geographical region (NAHMS, 1997). In Argentina, the animal-level prevalence was $84 \%$ in in dairy cattle (Trono et al., 2001). In a 1996 survey of dairy herds in the United States, the herd-level prevalence was 89\% (NAHMS, 1997), and in a 2007 dairy herd survey, the herd-level prevalence was $83.9 \%$ (NAHMS, 2008).

Ott et al. (2003) estimated the direct losses associated with clinical BLV infections to the dairy industry and consumers to be in excess of $\$ 500$ million yearly, and the economic losses associated with lymphoma have been estimated to be $\$ 412$ per case (Rhodes et al., 2003). Losses associated with subclinical infections (AL and PL), such as lost milk production, early culling, and possibly decreased reproductive efficiency and losses associated with reduced immune function, have rarely or never been quantified. At the herd level, several studies have shown a negative association between BLV antibodies and herd-level milk production (Sargeant et al., 1997; Ott et al., 2003; Erskine et al., 2012a). However, at the individual cow level, some studies found no association between BLV sero-positivity and milk production (Jacobs et al., 1991; Kale et al., 2007; Tiwari et al., 2007; Sorge et al., 2011).

The objectives of this paper were 2-fold: determine the association between the predicted 305-d matureequivalent (ME305) milk yields of individually tested 
cows in their lactation following BLV milk ELISA testing and (1) cow-level BLV sero-positive and seronegative status, and (2) different categories of corrected optical densities of the milk ELISA.

In this study, we used individual cow data from a subset of cows in Michigan dairy herds used in a previously reported study (Erskine et al., 2012a). As opposed to the study reported by Erskine et al. (2012a), which reported the herd-level effect of within-herd BLV prevalence on herd-level production and population age in Michigan dairy herds (Erskine et al., 2012a), we used only individual cows that were tested for BLV to investigate the effect of individual cows' BLV status on these cows' milk production.

\section{MATERIALS AND METHODS}

\section{Selection of Study Herds and Cows}

This study was part of a previously described project (Erskine et al., 2012a,b,c; Bartlett et al., 2013). In short, dairy herds in Michigan that routinely participated in DHI testing and averaged $\geq 120$ cows on test for the previous 12 mo were stratified into equally sized cohorts of 119 small herds (120-174 cows), 119 medium-sized herds (175-295 cows), and 119 large herds (296-6,492 cows). Within each of these strata, herds were assigned a random number which determined the order in which they were contacted and invited to participate in the study. We sought approximately 40 herds from each cohort. Some herds were excluded because of the inability to schedule herd visits and lack of data within herd DHI records before sampling. Within each herd, we identified up to 10 cows each from the first, second, third, and $\geq$ fourth lactations that were the most recently calved, based on the current DHI test. On the next DHI test day for each herd (June through August 2010), DHI technicians collected milk samples from the selected cows for submission to the laboratory (Antel BioSystems Inc., Lansing, MI) for milk ELISA testing for BLV antibodies (Erskine et al., 2012c). In short, milk samples were preserved immediately with $0.2 \mathrm{mg} /$ $\mathrm{mL}$ and $7.8 \mu \mathrm{g} / \mathrm{mL}$ natamycin (D\&F Control Systems Inc., Dublin, CA). Milk ELISA were performed within $5 \mathrm{~d}$ of sample collection (Erskine et al., 2012c).

\section{BLV-ELISA Testing}

The BLV milk assay is an antibody capture ELISA that is standardized using positive control samples and stopping the assay when the optical density (OD; 450 $\mathrm{mm})$ values of the positive controls are between 0.90 and 1.20 (Erskine et al., 2012c). Corrected milk-ELISA OD for milk samples were calculated by subtracting the average $\mathrm{OD}$ values of the negative controls from the OD value of each milk sample, and OD values $\geq 0.1$ were considered positive for previous BLV exposure.

Because of marketing-related decisions, dairy herds in the entire state of Michigan had not used bST throughout the 12-mo period before the initiation of our study in the summer of 2010 (Bartlett et al., 2013). Hence, rBST use will not act as a potential confounder in the analyses.

All animals included in this study were Holstein cows. Only $2(2 \%)$ and $3(3 \%)$ of 105 herds did not milk in a parlor or were tie-stall barns, respectively. Fifty-four herds (52\%) milked twice daily, 42 herds (39\%) milked 3 times per day, and 9 herds (9\%) milked part of their herd 2 or 3 times per day. Only one herd (1\%) did not feed a TMR, and in 8 herds (8\%), lactating cows had access to pasture.

\section{Statistical Analyses}

Descriptive Statistics. Individual cow data were exported from PCDART (Dairy Records Management Systems, Raleigh, NC) to Microsoft Excel (Microsoft Corp., Redmond, WA). Data management and descriptive statistics were performed in Stata 13.1 (StataCorp, College Station, TX). Descriptive statistics of BLV prevalence are presented as (1) herd prevalence, proportion of herds with one or more BLV-test positive cows; (2) within-herd prevalence, proportion of BLVpositive cows within each sampled herd; and (3) crude animal-level prevalence, proportion of cows positive for BLV across all sampled herds. Prevalence was calculated as point estimates and 95\% confidence intervals using the exact methods (Stata, 2013). Bi-variable and multivariable analyses were conducted in SAS 9.3 (SAS Institute Inc., Cary, NC).

Herd owners were provided with the mean prevalence for their herd, but did not see test results for individual animals. For the current analysis, we excluded herds with only 1 or 2 cows $(n=2)$, non-Holstein herds $(n=$ 4 ), and herds that did not have complete milk-ELISA OD information $(\mathrm{n}=2)$, and a total of 105 herds were used for the analyses.

Analytical Statistics. Explanatory variables were included as categorical or dichotomous variables because they were right skewed. A set of models by BLV status was created by testing the effects of lactation number categories (LACT), herd size (ONTEST), and warm versus cold seasons (SEAS) on ME305 of individual cows. Two variables reflecting BLV status were used in separate models. The first variable was based on milk-ELISA status (BLVSTAT; negative: OD $<0.1$, positive: $\geq 0.1$ ), and the second variable represented 4 BLV OD ordinal categories (ODCAT; 
$\mathrm{OD}<0.1,0.1 \leq \mathrm{OD}<0.25,0.25 \leq \mathrm{OD} \leq 0.5$, and $\mathrm{OD}$ $\geq 0.5$ ). A second set of models was built excluding first-lactation animals from the analysis, because firstlactation cows have more persistent lactation curves compared with higher lactation cows. The covariate SEAS, which was included because it may confound milk production, was dichotomized based on months with average temperature above and below an average high temperature of $15^{\circ} \mathrm{C}$. The cutoff of $15^{\circ} \mathrm{C}$ was chosen because it is considered the optimal ambient temperature for dairy cows. The months with average temperatures above $15^{\circ} \mathrm{C}$ included April, May, June, July, August, September, and October, and the remaining months had average temperatures below $15^{\circ} \mathrm{C}$. The ONTEST was included as a potential confounding variable. The distribution of ONTEST was not normal, so it was categorized into 5 categories: <150, 150-199, 200-299, 300-499, and $\geq 500$ cows.

All multivariable mixed-effects models (SAS, PROC MIXED), included herd (HRD) as a random effect, and it was assumed that the correlation among cows within a herd were identical. This modeling framework was used to model the association between ME305 and BLVSTAT and ME305 and ODCAT, adjusting for LACT, SEAS, and ONTEST as potential confounders. First-order interaction terms were created to account for potential effect modification by model variables, particularly BLV status and lactation number. Bivariable associations with $P<0.2$ were used in the multivariable models. Using the Type III $F$-test, a manual backward elimination procedure was used to build the final multivariable models until only significant covariates and significant and biologically meaningful 2-way interactions $(P<0.05)$ were retained. Residual distributions were assessed visually for nor- mality, and homoscedasticity of BLV and ODCAT variances was assessed using the GROUP command in the REPEATED statement in PROC MIXED. Least squares means were obtained for significant covariates. Comparisons of LSM for BLVSTAT and ODCAT were conducted using the Bonferroni adjustment for multiple comparisons. To obtain a surrogate for the $\mathrm{R}^{2}$ for all the models described above, a measure of the percent variance explained by the covariates in the models, the effects of BLVSTAT and ODCAT and other covariates were also estimated using a regression model (PROC GLM) using HRD as a fixed effect.

\section{RESULTS}

\section{Descriptive Data}

One hundred and five Michigan dairy herds were included in this study, and the herd size ranged from 116 to 6,492 lactating cows. At the time herds were selected, they all reported having $\geq 120$ milking cows. A total of 3,789 cows were used to evaluate the effect of BLVSTAT (OD $<0.1$ and OD $\geq 0.1$ ) and ODCAT $(\mathrm{OD}<0.1,0.1 \leq \mathrm{OD}<0.25,0.25 \leq \mathrm{OD}<0.5$, and $\mathrm{OD} \geq 0.5)$ on ME305. The distribution of cows in the 4 lactation categories (LACT) was 957, 977, 939, and 916 cows, respectively; and 694, 1,036, 740, 685, and 634 cows were present in the 5 herd-size categories (ONTEST), respectively. The distribution of cows by SEAS was 967 and 2,822 in seasons with an average temperature below and above $15^{\circ} \mathrm{C}$, respectively (Table 1). The mean ME305 milk production across all cows was 11,354 kg (95\% CI: 11,290-11,419) (Table 1).

Bovine leukemia virus infected cows were not detected in 15 herds, hence the BLV herd prevalence was

Table 1. Distributions of the crude within-herd bovine leukemia virus (BLV) prevalence (\%), the within-herd prevalence (\%) of cows in the 4 optical density (OD) categories, the within-herd prevalence (\%) of BLV-positive cows in the 3 OD categories representing BLV-positive cows, and 305-d mature equivalent milk production across 3,789 cows in 105 Michigan dairy herds

\begin{tabular}{|c|c|c|c|c|c|c|c|c|}
\hline Variable & $\begin{array}{l}\text { Number } \\
\text { of herds }\end{array}$ & Mean & SD & Minimum & $\begin{array}{c}25 \text { th } \\
\text { percentile }\end{array}$ & $\begin{array}{c}50 \text { th } \\
\text { percentile }\end{array}$ & $\begin{array}{c}75 \text { th } \\
\text { percentile }\end{array}$ & Maximum \\
\hline Within-herd prevalence & $\begin{array}{c}105 \\
(3,789 \text { cows })\end{array}$ & 33.6 & 23.7 & 0 & 15.8 & 32.3 & 52.9 & 78.1 \\
\hline $\mathrm{OD}<0.1$ & 105 & 66.4 & 23.7 & 21.9 & 47.1 & 67.7 & 84.2 & 100.0 \\
\hline $0.1 \leq \mathrm{OD}<0.25$ & 88 & 12.6 & 7.8 & 2.6 & 6.5 & 10.4 & 17.4 & 39.5 \\
\hline $0.25 \leq \mathrm{OD}<0.5$ & 86 & 16.7 & 9.2 & 2.6 & 8.1 & 15.6 & 23.7 & 35.7 \\
\hline $0.1 \leq \mathrm{OD}<0.25$ & 88 & 35.5 & 19.1 & 10 & 24.0 & 32.7 & 42.0 & 100.0 \\
\hline $0.25 \leq \mathrm{OD}<0.5$ & 86 & 42.5 & 14.1 & 8.3 & 31.8 & 42.0 & 50.0 & 80.0 \\
\hline $\mathrm{OD} \geq 0.5$ & 78 & 29.6 & 15.2 & 6.7 & 17.9 & 25 & 41.7 & 66.7 \\
\hline Milk production, mature equivalents $(\mathrm{kg})$ & 3,789 & 11,354 & 2,030 & 3,708 & 10,060 & 11,336 & 12,641 & 18,964 \\
\hline
\end{tabular}

${ }^{1}$ ODCAT $=$ ordinal categories. 
Table 2. Bivariable analysis estimating association between 305-d mature-equivalent milk production and bovine leukemia virus (BLVSTAT), ordinal categories (ODCAT), lactation number categories (LACT), warm versus cold seasons (SEAS), and herd size (ONTEST), including all lactations $(\mathrm{n}=3,789)^{1}$

\begin{tabular}{|c|c|c|c|c|c|c|}
\hline Parameter & $\mathrm{n}$ & Estimate & $\mathrm{SE}$ & $P$-value & ICC & $\mathrm{R}^{2}$ \\
\hline \multicolumn{7}{|l|}{ BLVSTAT } \\
\hline Intercept & & $11,165.0$ & 115.2 & 0.0003 & 0.27 & 0.29 \\
\hline $\mathrm{OD}<0.1$ & 2,507 & 249.4 & 68.2 & & & \\
\hline $\mathrm{OD} \geq 0.1$ & 1,282 & - & - & & & \\
\hline \multicolumn{7}{|l|}{ ODCATT } \\
\hline Intercept & & $10,909.0$ & 140.1 & $<0.0001$ & 0.27 & 0.29 \\
\hline $\mathrm{OD}<0.1$ & 2,507 & 506.8 & 105.3 & & & \\
\hline $0.1 \leq \mathrm{OD}<0.25$ & 403 & 387.2 & 128.6 & & & \\
\hline $0.25 \leq \mathrm{OD}<0.5$ & 516 & 326.7 & 121.1 & & & \\
\hline $\mathrm{OD} \geq 0.5$ & 363 & - & - & & & \\
\hline \multicolumn{7}{|l|}{$\mathrm{LACT}$} \\
\hline Intercept & & $10,786.0$ & 119.4 & $<0.0001$ & 0.29 & 0.33 \\
\hline Lactation 1 & 957 & 476.3 & 78.1 & & & \\
\hline Lactation 2 & 977 & $1,119.8$ & 77.7 & & & \\
\hline Lactation 3 & 939 & 538.4 & 78.4 & & & \\
\hline \multirow{2}{*}{\multicolumn{7}{|c|}{ SEAS }} \\
\hline & & & & & & \\
\hline Intercept & & $11,237.0$ & 109.6 & $<0.0001$ & 0.27 & 0.30 \\
\hline 0 (Month $\left.<15^{\circ} \mathrm{C}\right)$ & 967 & 364.3 & 72.8 & & & \\
\hline 1 (Month $>15^{\circ} \mathrm{C}$ ) & 2,822 & - & - & & & \\
\hline \multicolumn{7}{|l|}{ ONTEST } \\
\hline Intercept & & $10,858.0$ & 261.3 & 0.326 & 0.27 & 0.29 \\
\hline $1(<150)$ & 694 & 675.7 & 360.6 & & & \\
\hline $2(150-199)$ & 1,036 & 654.1 & 334.7 & & & \\
\hline $3(200-299)$ & 740 & 453.6 & 359.9 & & & \\
\hline $4(300-499)$ & 685 & 451.3 & 364.7 & & & \\
\hline $5(\geq 500)$ & 634 & - & - & & & \\
\hline
\end{tabular}

85.7\% (95\% CI: $77.5-91.8 \%)$, and the crude animallevel prevalence was $33.6 \%$ (95\% CI: 32.3-35.4\%). The within-herd BLV prevalence ranged from 0 to $78.1 \%$ (Table 1). The within-herd proportion of cows in the 4 OD categories ranged from 21.0 to $100 \%, 2.6$ to $39.5 \%$, 2.6 to $37.5 \%$, and 2.5 to $37.5 \%$ for OD $<0.1,0.1<\mathrm{OD}$ $<0.25,0.25<\mathrm{OD}<0.5$, and $\mathrm{OD}>0.5$, respectively (Table 1).

\section{Effect of BLV Status on Milk Production for All Cows}

Bi-variable analyses for all cows are shown in Table 2. The analysis including BLVSTAT is shown in Table 3. Adjusted for lactation number and calving season, the LSM ME305 milk production in BLV-positive cows was on average $132.4 \mathrm{~kg}(1.1 \%)$ less than in BLVnegative cattle $(P=0.052$; Table 3$)$. Across lactations,

Table 3. Multivariable analysis model for 305-d mature-equivalent milk production and bovine leukemia virus (BLVSTAT) status, including all lactations $(\mathrm{n}=3,789)^{1}$

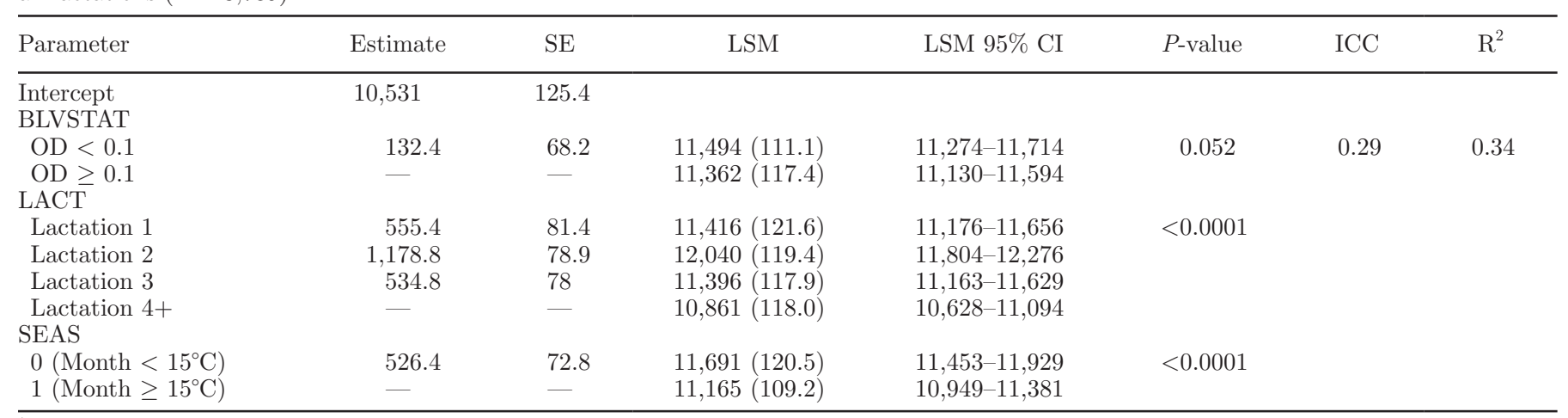

${ }^{1}$ Likelihood ratio test for homogeneous variance for BLV $(P=0.29)$. ICC $=$ intraclass correlation coefficient. OD $=$ optical density. LACT $=$ lactation number categories. SEAS = warm versus cold seasons. $\mathrm{R}^{2}$ was determined using a generalized linear model including herd as a fixed effect. 
only the comparison between first and third lactation cows did not differ significantly. Cows calving during warmer months produced on average $526.4 \mathrm{~kg}$ less milk as compared with cows calving during cooler months $(P<0.0001)$.

\section{Effect of OD Category on Milk Production for All Cows}

Estimating the effect of increasing milk-ELISA OD (ODCAT), cows with an OD $\geq 0.5$ produced $352.8 \mathrm{~kg}$ $(3.1 \%)$ less $(P<0.05)$ milk than BLV negative (OD $<0.1), 309.1 \mathrm{~kg}(2.7 \%)$ less than cows in the OD group $0.1 \leq \mathrm{OD}<0.25(P<0.05)$, and $303.3(2.6 \%)$ less milk than cows in the $0.25<\mathrm{OD} \leq 0.5$ group $(P<0.05$; Table 4). A significant difference was not found in milk production between groups with $\mathrm{OD}<0.1,0.1 \leq \mathrm{OD}$ $\leq 0.25$ and $0.25<\mathrm{OD} \leq 0.5$. A significant interaction was found between ODCAT and LACT $(P<0.05)$.

\section{Effect of BLV Status on Milk Production for Lactation 2 and Higher Cows}

Bi-variable analyses for lactation 2 and higher cows are shown in Table 5. For the multivariable model estimating the effect of BLVSTAT and excluding the lactation 1 cows, BLV-positive cows produced $177.3 \mathrm{~kg}$ $(1.5 \%)$ less milk $(P<0.05)$ than BLV-negative cattle (Table 6).

\section{Effect of OD Category on Milk Production for Lactation 2 and Higher Cows}

The multivariable model estimating the effect of different ODCAT on milk production showed that cows with an OD $\geq 0.5$ produced $499.1 \mathrm{~kg}(4.3 \%)$ less milk ( $P$ $<0.05)$ than BLV-negative cows (OD $<0.1)$, and 488.9 $\mathrm{kg}(4.2 \% ; P<0.05)$ and $370.3 \mathrm{~kg}(3.2 \% ; P<0.05)$ less milk than OD groups $0.1 \leq \mathrm{OD}<0.25$ and $0.25<\mathrm{OD}$

Table 4. Multivariable analysis model for 305-d mature-equivalent milk production and ordinal categories (ODCAT), including all lactations $(\mathrm{n}=3,789)^{1}$

\begin{tabular}{|c|c|c|c|c|c|c|c|}
\hline Parameter & Estimate & SE & LSM & LSM $95 \%$ CI & $P$-value & ICC & $\mathrm{R}^{2}$ \\
\hline \multicolumn{8}{|l|}{ ODCAT } \\
\hline $\mathrm{OD}<0.1$ & 121.9 & 164.4 & 11,500 & $11,280-11,720$ & 0.016 & & \\
\hline $0.25 \leq \mathrm{OD}<0.5$ & -101.2 & 197.9 & 11,450 & $11,190-11,710$ & & & \\
\hline $\mathrm{OD} \geq 0.5$ & & & 11,147 & $10,861-11,434$ & & & \\
\hline \multicolumn{8}{|l|}{ LACT } \\
\hline Lactation 3 & 73.7 & 218.4 & 11,291 & $11,043-11,539$ & & & \\
\hline Lactation $4+$ & 0 & - & 10,825 & $10,584-11,067$ & & & \\
\hline \multicolumn{8}{|l|}{ SEAS } \\
\hline $0\left(\right.$ month $\left.<15^{\circ} \mathrm{C}\right)$ & 523.7 & 72.7 & 11,650 & $11,406-11,895$ & $<0.001$ & & \\
\hline $1\left(\right.$ month $\left.\geq 15^{\circ} \mathrm{C}\right)$ & & & 11,126 & $10,903-11,350$ & & & \\
\hline \multicolumn{8}{|l|}{ ODCAT $\times \overline{\mathrm{LACT}^{2}}$} \\
\hline $0 \times 1$ & -124.5 & 303.4 & & & 0.034 & & \\
\hline $1 \times 3$ & 530.8 & 242.2 & & & & & \\
\hline $1 \times 4$ & 0 & - & & & & & \\
\hline $2 \times 1$ & 278.4 & 369.8 & & & & & \\
\hline $2 \times 2$ & 916.7 & 321.6 & & & & & \\
\hline $2 \times 3$ & 422.7 & 291.8 & & & & & \\
\hline $2 \times 4$ & 0 & - & & & & & \\
\hline $3 \times 1$ & 0 & - & & & & & \\
\hline $3 \times 2$ & 0 & - & & & & & \\
\hline $3 \times 3$ & 0 & - & & & & & \\
\hline $3 \times 4$ & 0 & - & & & & & \\
\hline
\end{tabular}

${ }^{1}$ Likelihood test for homogeneous variance for BLV $(P=0.02)$. ICC $=$ intraclass correlation coefficient. OD $=$ optical density. LACT $=$ lactation number categories. SEAS = warm versus cold seasons. $\mathrm{R}^{2}$ was determined using a generalized linear model including herd as a fixed effect. ${ }^{2}$ Interaction term of ODCAT and LACT. 
Table 5. Bi-variable analysis estimating association between 305-d mature-equivalent milk production and bovine leukemia virus (BLVSTAT), ordinal categories (ODCAT), lactation number categories (LACT), warm versus cold seasons (SEAS), and herd size (ONTEST), without firstlactation cows $(\mathrm{n}=2,832)^{1}$

\begin{tabular}{|c|c|c|c|c|c|c|}
\hline Parameter & $\mathrm{n}$ & Estimate & $\mathrm{SE}$ & $P$-value & ICC & $\mathrm{R}^{2}$ \\
\hline Intercept & & 11,133 & 121.6 & \multirow[b]{2}{*}{$<0.0001$} & \multirow[b]{2}{*}{0.28} & \\
\hline $\mathrm{OD}<0.1$ & 1,736 & 362.1 & 80.0 & & & 0.32 \\
\hline \multicolumn{7}{|l|}{ ODCAT } \\
\hline Intercept & & 10,822 & 149.4 & \multirow[t]{3}{*}{$<0.0001$} & \multirow[t]{3}{*}{0.28} & \multirow[t]{3}{*}{0.32} \\
\hline $\mathrm{OD}<0.1$ & 1,736 & 676.2 & 118.8 & & & \\
\hline $\mathrm{OD} \geq 0.5$ & 317 & & & & & \\
\hline \multicolumn{7}{|l|}{ LACT } \\
\hline Intercept & & 10,789 & 124.1 & \multirow[t]{4}{*}{$<0.0001$} & \multirow[t]{4}{*}{0.31} & \multirow[t]{4}{*}{0.36} \\
\hline Lactation 2 & 977 & $1,116.0$ & 78.4 & & & \\
\hline Lactation 3 & 939 & 539.5 & 79.1 & & & \\
\hline Lactation $4+$ & 916 & & & & & \\
\hline \multicolumn{7}{|l|}{ Season } \\
\hline $1(<150)$ & 519 & 765.8 & 380.8 & \multirow{5}{*}{0.299} & \multirow{5}{*}{0.29} & \multirow{5}{*}{0.31} \\
\hline $2(150-199)$ & 776 & 681.2 & 353.5 & & & \\
\hline $3(200-299)$ & 552 & 514.9 & 380.1 & & & \\
\hline $4(300-499)$ & 509 & 514.8 & 385.3 & & & \\
\hline $5(\geq 500)$ & 476 & & & & & \\
\hline
\end{tabular}

${ }^{1} \mathrm{ICC}=$ intraclass correlation coefficient. OD $=$ optical density. $\mathrm{R}^{2}$ was determined using a generalized linear model including herd as a fixed effect.

$\leq 0.5$, respectively (Table 7 ). A significant interaction was found between ODCAT and LACT $(P<0.05)$.

Visual assessment of residual plots indicated that the residuals were normally distributed for all the models mentioned above. The variance was homogeneous between categories for all models except for the model including ODCAT for all cows $(P=0.02$; Table 4$)$. Using linear regression with herd as a fixed effect, the estimated variance explained by the variables included in each of the multivariable models ranged between 34 and $38 \%$. The variance contributed by HRD was 29 and $30 \%$ for the models including the BLVSTAT and ODCAT, respectively.

\section{DISCUSSION}

Although BLV has been demonstrated to decrease milk production at the herd level (Sargeant et al., 1997; Ott et al., 2003; Erskine et al., 2012a), this study may be the first to report a negative association of BLV milk-positivity (BLVSTAT) and ELISA OD (ODCAT) on individual cow ME305. Despite

Table 6. Multivariable analysis model for 305-d mature-equivalent milk production and bovine leukemia virus (BLVSTAT), without firstlactation cows $(\mathrm{n}=2,832)^{1}$

\begin{tabular}{|c|c|c|c|c|c|c|c|}
\hline Parameter & Estimate & $\mathrm{SE}$ & LSM & LSM 95\% CI & $P$-value & ICC & $\mathrm{R}^{2}$ \\
\hline \multicolumn{8}{|l|}{ BLVSTAT } \\
\hline $\mathrm{OD}<0.1$ & 177.3 & 78.0 & 11,529 & $11,296-11,762$ & \multicolumn{3}{|l|}{0.023} \\
\hline \multicolumn{8}{|l|}{ LACT } \\
\hline Lactation 2 & $1,175.0$ & 79.8 & 12,046 & $11,801-12,291$ & \multicolumn{3}{|l|}{$<0.0001$} \\
\hline Lactation 3 & 532.9 & 78.7 & 11,404 & $11,163-11,646$ & & & \\
\hline \multicolumn{8}{|l|}{ SEAS } \\
\hline $0\left(\right.$ months $\left.<15^{\circ} \mathrm{C}\right)$ & 579.2 & 80.3 & 11,730 & $11,481-11,979$ & $<0.0001$ & & \\
\hline 1 (months $\left.\geq 15^{\circ} \mathrm{C}\right)$ & & & 11,151 & $10,923-11,379$ & & & \\
\hline
\end{tabular}

${ }^{1}$ Likelihood test for homogeneous variance for BLV $(P=0.37)$. ICC $=$ intraclass correlation coefficient. OD $=$ optical density. LACT $=$ lactation number categories. SEAS = warm versus cold seasons. $\mathrm{R}^{2}$ was determined using a generalized linear model including herd as a fixed effect. 
Table 7. Multivariable analysis model for 305-d mature-equivalent milk production and ordinal categories (ODCAT), without first-lactation cows $(\mathrm{n}=2,832)^{1}$

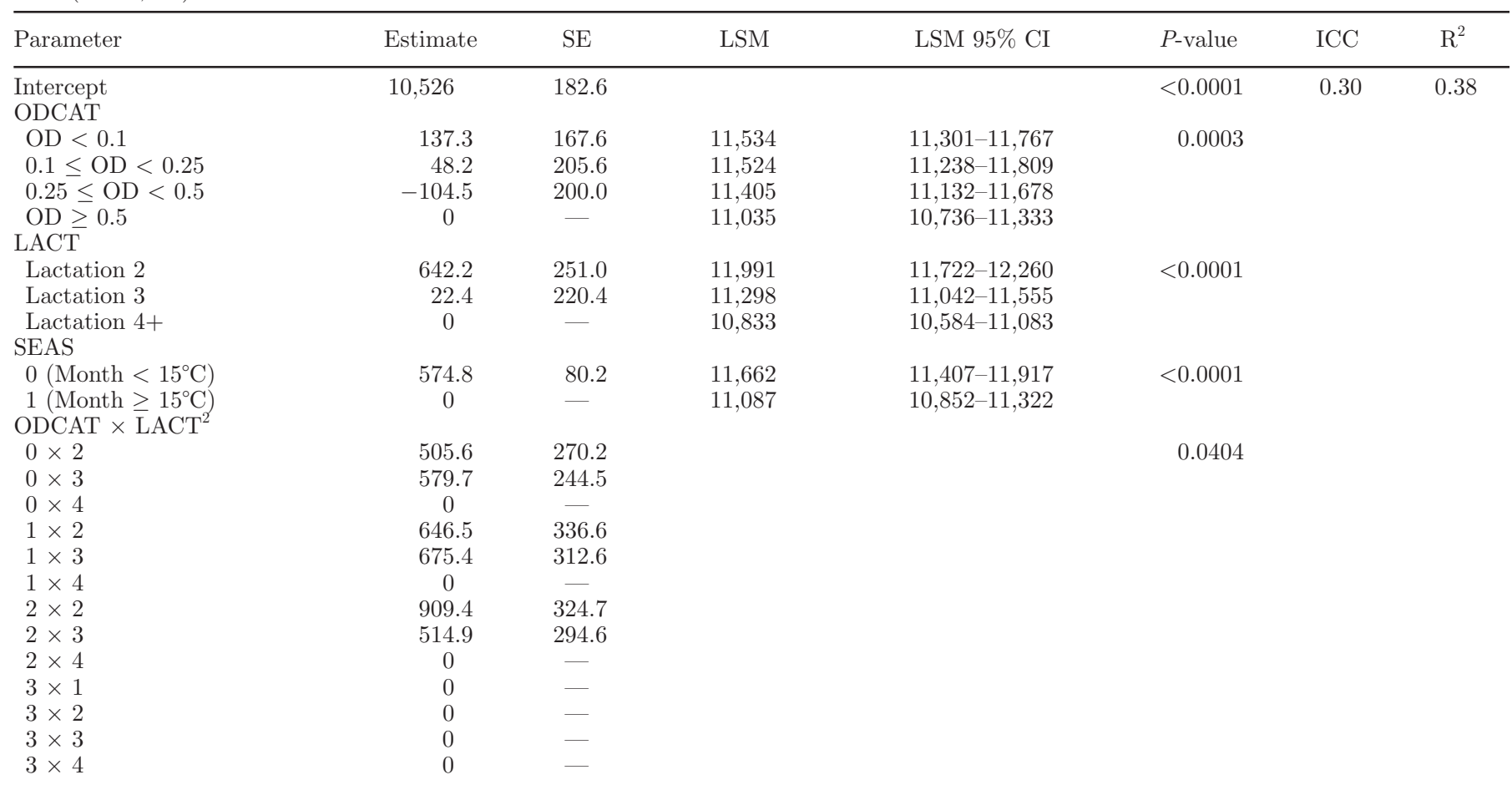

${ }^{1}$ Likelihood test for homogeneous variance for bovine leukemia virus $(P=0.13)$. ICC $=$ intraclass correlation coefficient. OD $=$ optical density. $\mathrm{LACT}=$ lactation number categories. SEAS $=$ warm versus cold season. $\mathrm{R}^{2}$ was determined using a generalized linear model including herd as a fixed effect.

${ }^{2}$ Interaction term of ODCAT and LACT.

adjustment for similar covariate patterns (lactation, season, and herd size), this finding is in contrast to other studies that did not demonstrate such an association at the cow level (Jacobs et al., 1991; Kale et al., 2007; Tiwari et al., 2007; Sorge et al., 2011). We cannot know with certainty the reason for the discrepancy in findings between these studies and the data set presented here. However, we can speculate about the presence of differences in study and sampling designs and indirect effects of other health events as well as differences in herd sizes and compositions that may affect cows' ME305. Differences were also present in the BLV testing method, and it is possible that differences in BLV strains may affect the effect of BLV infections on milk production. The discrepancy between Kale et al. (2007) and our study may be explained by only one herd being used in that study.

In the studies by Jacobs et al. (1991) and Tiwari et al. (2007), herds were selected at random in Ontario and across 5 southern Canadian provinces, respectively. In the study by Jacobs et al. (1991), more than $80 \%$ of cows in herds were sampled and for Tiwari et al. (2007) 30 cows (if present) were sampled in each herd. For all 3 studies, the overall animal-level prevalence [29\% (Tiwari), 36\% (Jacobs), and 34\% (this study)] likely did not explain differences in study outcomes. However, for the study by Jacobs et al. (1991) different study outcomes could be explained by the use of small herds (mean of 44 cows/herd), that the potential confounding effect of herd was not accounted for by inclusion of random effect for herd, and potentially that their model used ME305 to predict BLV status and not vice versa as in the study by Tiwari et al. (2007) and this study. It is unclear why a discrepancy is present between the outcome of our study and the study by Tiwari et al. (2007). Although the study by Tiwari et al. (2007) included approximately twice as many cows as our study and a much larger geographical area, the number of cows sampled per herd were similar (30 vs. 40). However, the sampling scheme for selecting cows within herds differed between the Tiwari study and ours. The mixed-effects multivariable linear model used by Tiwari et al. (2007) included cows' serological response to BLV, bovine viral diarrhea virus, Мycobacterium avium ssp. paratuberculosis, and Neospora caninum. However, no significant effect modification was found of sero-positivity by other pathogens on BLV. Nonetheless, variables not included in our models (and included in others' models) might have introduced residual confounding of our results. 
A potential reason for difficulties determining an association between BLV status and ME305 at the individual-cow level may also be explained by the fact that good farm managers quickly cull poor-producing cows, thereby minimizing the milk production effect of BLV infection and essentially transferring these losses from costs associated with lost milk production to losses associated with poor cow longevity (Bartlett et al., 2013). Additionally, the ME305 excludes aberrantly low milk values from its calculation of ME305 and also excludes cows that have been put on a list of cows to be culled.

The milk ELISA used in this study has high sensitivity (98.1\%) and specificity (98.9\%; Antel Biosystems Inc., 2015) and has been reported to agree very well with serum ELISA results (Walsh et al., 2013). Furthermore, the milk ELISA is semiquantitative as the assay is standardized against a positive control and higher OD are likely correlated with higher levels of BLV antibodies in milk. In the current study, the negative association with ME305 increased with increasing OD of the milk ELISA test. Specifically, the negative effect on ME305 was most noticeable in cows within the highest category (ODCAT $\geq 0.5$ ). In the model using all cows, we observed a $3.1 \%$ loss of ME305 and observed a $4.2 \%$ loss when analyzing only multiparous cows. The difference in LSM of ME305 was much smaller for the other OD categories when compared with BLV-negative cows. This suggests a dose effect whereby increasing antibody levels have an increasingly negative association with ME305, which is also consistent with the hypothesis that BLV infection could be causally related to decreasing milk production and longevity.

Previous work on essentially this same database has shown a dose-response effect of BLV ELISA OD on cow longevity (Bartlett et al., 2013). The decreasing milk production associated with increasing ODCAT could be explained by BLV-infected cows transitioning from the AL state to becoming PL, and some evidence indicates increasing antibody levels are correlated with progression of BLV in cattle that have increasing circulating absolute numbers of lymphocytes (Juliarena et al., 2007). Nonetheless, it is unknown exactly how BLV infection may affect milk production; however, it may, to some extent, be explained by BLV infection of mammary epithelial cells (Buehring et al., 1994; Motton and Buehring, 2003) or BLV-induced immune suppression affecting overall health. Motton and Buehring (2003) showed BLV may not be an innocuous factor in BLV-infected cows, as it affects the differentiation of mammary epithelial cells and may begin the trajectory of cows toward malignant transformation of mammary epithelial cells. Additionally, PL cows have been shown to be culled earlier and have lower milk production during the lactation they were culled (Pollari et al., 1992), and in an Illinois study it was also reported that cows had increasing milk loss with increasing duration of PL (Da et al., 1993).

Those cattle that become PL cattle have a polyclonal expansion of peripheral B cells $(>10,000 / \mu \mathrm{L})$. The proviral load also increases in PL cows, likely making them more infectious to herdmates (Juliarena et al., 2007; Esteban et al., 2009). An increase in peripheral blood B lymphocytes is the most obvious immunological effect of BLV and may be diagnostic of immunosuppression in the pathogenesis of this disease. However, strong evidence was found that overall immune function is negatively affected in all BLV-positive cows. B cells are the primary target for BLV, but T cells (Lavanya et al., 2008) and monocytes (Altreuther et al., 2001) are also affected. Bovine leukemia virus induces an accumulation of B cells in blood and lymphoid tissue (Sordillo et al., 1994; Debacq et al., 2003; Florins et al., 2008), and B cell survival is dysregulated in BLV-positive cattle (Dequiedt et al., 1999; Cantor et al., 2001; Florins et al., 2008). Additionally, significant changes were found in circulating T cell levels (Stone et al., 1995; Erskine et al., 2011b), with a significant decrease in $\mathrm{CD} 4^{+}$and $\mathrm{CD}^{+}{ }^{+} \mathrm{T}$ cells (Sordillo et al., 1994), $\mathrm{T}$ cell sensitivity to mitogen stimulation is decreased (Stone et al., 1995, 2000), and remaining T cells exhibit decreased proinflammatory cytokine secretion, particularly IFN (Pyeon et al., 1996). Monocytes from BLV-infected cattle also have decreased phagocytotic activity as compared with monocytes from BLV-negative cattle (Werling et al., 1998). Altogether, this immune suppression may negatively alter milk yield by allowing opportunistic infections, as is seen with other retroviral infections (e.g., HIV).

Few studies have investigated the effect of BLV infection on the incidence of other diseases and effectiveness of immunization. However, it has been demonstrated that BLV-infected cattle had reduced levels of anti-J5 specific $\mathrm{IgG}_{2}$ as compared with BLV-negative cattle following vaccination, and that apoptosis and cell death were increased among $\mathrm{T}$ cells in PL as compared with AL cows (Erskine et al., 2011a,b). Furthermore, a study of 14,424 Swedish herds (Emanuelson et al., 1992) showed that BLV-infected herds had a marked tendency for diseases of possible infectious etiology, including mastitis, gastrointestinal, bronchial diseases, and hoof problems. Another study showed a lack of spontaneous recovery from ringworm (Trichophyton verrucosum) infection (Trainin et al., 1996).

Our study has some inherent limitations that could have biased our results. It is possible that the decision of herd owners not to participate in the study or herds excluded from the study data were somehow associated with management factors or other factors affecting 
their BLV status and its effect on individual cows' milk production. Likewise, the herds included in this study participated in DHI testing to facilitate sampling of milk on DHI testing day, and it is possible that such herds are managed differently from other dairy herds, which in turn may affect the associations we determined between BLV status and milk production. Additional bias or confounding may have occurred from extraneous variables that were not measured and included in our models and our survey could not discriminate potential compliance of reporting management practices. The potential biases in this study can be defined as selection bias, and it is not possible to determine whether they would increase or decrease the strength of association we determined between an individual cow's BLV status and its milk production. These biases may limit generalizability from our study to other herds in Michigan and the United States in general.

Explaining the interaction between BLV pathogenesis, milk yield, health outcomes, and immune function cannot be definitively determined using cross-sectional studies like the one presented here. Only longitudinal studies following cows over longer periods of time, measuring new infections and progression of infections and the immune function will yield definitive answers to many of the questions raised above.

\section{ACKNOWLEDGMENTS}

The authors thank the Elwood Kirkpatrick Dairy Science Research Endowment (Michigan State University, East Lansing) for funding this project as well as the participating dairy farms and Antel Biosystems Inc. (Lansing, MI) for technical assistance.

\section{REFERENCES}

Altreuther, G., L. Llames, S. Neuenschwander, W. Langhans, and D. Werling. 2001. Morphologic and functional changes in bovine monocytes infected in vitro with the bovine leukaemia virus. Scand. J. Immunol. 54:459-469.

Antel Biosystems Inc. 2015. Bovine Leukosis Virus (BLV) ELISA. Vol. 2015. Accessed Dec. 12, 2015. http://www.antelbio.com/ WebReportsResults/Bovine\%20Leukosis\%20Virus\%20ELISA. html.

Bartlett, P. C., B. Norby, T. M. Byrem, A. Parmelee, J. T. Ledergerber, and R. J. Erskine. 2013. Bovine leukemia virus and cow longevity in Michigan dairy herds. J. Dairy Sci. 96:1591-1597.

Batho, H., H. Bendixen, H. Meyer-Gerbaulet, and J. Westergaard. 2008. The EU Veterinarian. Accessed Dec. 12, 2015. http:// ec.europa.eu/food/resources/the_eu_veterinarian_080410.pdf.

Buehring, G. C., P. M. Kramme, and R. D. Schultz. 1994. Evidence for bovine leukemia virus in mammary epithelial cells of infected cows. Lab. Invest. 71:359-365.

Cantor, G. H., S. M. Pritchard, F. Dequiedt, L. Willems, R. Kettmann, and W. C. Davis. 2001. CD5 is dissociated from the B-cell receptor in B cells from bovine leukemia virus-infected, persistent- ly lymphocytotic cattle: Consequences to B-cell receptor-mediated apoptosis. J. Virol. 75:1689-1696.

Da, Y., R. D. Shanks, J. A. Stewart, and H. A. Lewin. 1993. Milk and fat yields decline in bovine leukemia virus-infected Holstein cattle with persistent lymphocytosis. Proc. Natl. Acad. Sci. USA 90:6538-6541.

Debacq, C., B. Asquith, M. Reichert, A. Burny, R. Kettmann, and L. Willems. 2003. Reduced cell turnover in bovine leukemia virus-infected, persistently lymphocytotic cattle. J. Virol. 77:13073-13083.

Dequiedt, F., G. H. Cantor, V. T. Hamilton, S. M. Pritchard, W. C. Davis, P. Kerkhofs, A. Burny, R. Kettmann, and L. Willems. 1999. Bovine leukemia virus-induced persistent lymphocytosis in cattle does not correlate with increased ex vivo survival of B lymphocytes. J. Virol. 73:1127-1137.

Emanuelson, U., K. Scherling, and H. Pettersson. 1992. Relationships between herd bovine leukemia-virus infection status and reproduction, disease incidence, and productivity in Swedish dairy herds. Prev. Vet. Med. 12:121-131.

Erskine, R. J., P. C. Bartlett, T. M. Byrem, C. L. Render, C. Febvay, and J. T. Houseman. 2012a. Association between bovine leukemia virus, production, and population age in Michigan dairy herds. J. Dairy Sci. 95:727-734.

Erskine, R. J., P. C. Bartlett, T. M. Byrem, C. L. Render, C. Febvay, and J. T. Houseman. 2012b. Herd-level determinants of bovine leukaemia virus prevalence in dairy farms. J. Dairy Res. 79:445-450.

Erskine, R. J., P. C. Bartlett, T. M. Byrem, C. L. Render, C. Febvay, and J. T. Houseman. 2012c. Using herd profile to determine age-specific prevalence of bovine leukemia virus in Michigan dairy herds. Vet. Med. Int. 2012:350374.

Erskine, R. J., P. C. Bartlett, K. M. Sabo, and L. M. Sordillo. 2011a. Bovine leukemia virus infection in dairy cattle: Effect on serological response to immunization against J5 Escherichia coli bacterin. Vet. Med. Int. 2011:915747.

Erskine, R. J., C. M. Corl, J. C. Gandy, and L. M. Sordillo. 2011b. Effect of infection with bovine leukosis virus on lymphocyte proliferation and apoptosis in dairy cattle. Am. J. Vet. Res. 72:1059-1064.

Esteban, E. N., M. Poli, B. Poiesz, C. Ceriani, S. Dube, S. Gutierrez, G. Dolcini, R. Gagliardi, S. Perez, C. Lutzelschwab, L. Feldman, and M. Juliarena. 2009. Bovine Leukemia virus (BLV), proposed control and eradication programs by marker assisted breeding of genetically resistant cattle. Pages 1-25 in Animal Genetics. L. J. Rechi, ed. Nova Science Publishers Inc., New York, NY.

Florins, A., M. Boxus, F. Vandermeers, O. Verlaeten, A. B. Bouzar, J. Defoiche, R. Hubaux, A. Burny, R. Kettmann, and L. Willems. 2008. Emphasis on cell turnover in two hosts infected by bovine leukemia virus: A rationale for host susceptibility to disease. Vet. Immunol. Immunopathol. 125:1-7.

Jacobs, R. M., J. L. Heeney, M. A. Godkin, K. E. Leslie, J. A. Taylor, C. Davies, and V. E. Valli. 1991. Production and related variables in bovine leukaemia virus-infected cows. Vet. Res. Commun. $15: 463-474$.

Juliarena, M. A., S. E. Gutierrez, and C. Ceriani. 2007. Determination of proviral load in bovine leukemia virus-infected cattle with and without lymphocytosis. Am. J. Vet. Res. 68:1220-1225.

Kabeya, H., K. Ohashi, and M. Onuma. 2001. Host immune responses in the course of bovine leukemia virus infection. J. Vet. Med. Sci. 63:703-708.

Kale, M., O. Bulut, O. Yapkic, M. S. Gulay, F. Pehlivanoglu, A. Ata, and S. Yavru. 2007. Effects of subclinical bovine leukemia virus infection on some production parameters in a dairy farm in southern Turkey. J. S. Afr. Vet. Assoc. 78:130-132.

Lavanya, M., S. Kinet, A. Montel-Hagen, C. Mongellaz, J. L. Battini, M. Sitbon, and N. Taylor. 2008. Cell surface expression of the bovine leukemia virus-binding receptor on $\mathrm{B}$ and $\mathrm{T}$ lymphocytes is induced by receptor engagement. J. Immunol. 181:891-898.

Motton, D. D., and G. C. Buehring. 2003. Bovine leukemia virus alters growth properties and casein synthesis in mammary epithelial cells. J. Dairy Sci. 86:2826-2838.

NAHMS. 1997. High Prevalence of BLV in U.S. Dairy Herds. 1996 USDA APHIS VS, Centers for Epidemiology and Animal Health. USDA, Washington, DC. 
NAHMS. 2008. Bovine Leukosis virus (BLV) on U.S. Dairy Operations, 2007. USDA, APHIS, VS, Centers for Epidemiology and Animal Health. USDA, Washington, DC.

OIE. 2012. Manual of Diagnostic tests and Vaccines for Terrestrial Animals. in Enzootic Bovine Leukosis Chapter 2.4.11. 7th ed. World Organization for Animal Health (OIE). Paris, France.

Ott, S. L., R. Johnson, and S. J. Wells. 2003. Association between bovine-leukosis virus seroprevalence and herd-level productivity on US dairy farms. Prev. Vet. Med. 61:249-262.

Pollari, F. L., V. L. Wangsuphachart, R. F. DiGiacomo, and J. F. Evermann. 1992. Effects of bovine leukemia virus infection on production and reproduction in dairy cattle. Can. J. Vet. Res. 56:289-295.

Pyeon, D., K. L. O'Reilly, and G. A. Splitter. 1996. Increased interleukin-10 mRNA expression in tumor-bearing or persistently lymphocytotic animals infected with bovine leukemia virus. J. Virol. 70:5706-5710.

Rhodes, J. K., K. D. Pelzer, and Y. J. Johnson. 2003. Economic implications of bovine leukemia virus infection in mid-Atlantic dairy herds. J. Am. Vet. Med. Assoc. 223:346-352.

Sargeant, J. M., D. F. Kelton, S. W. Martin, and E. D. Mann. 1997. Associations between farm management practices, productivity, and bovine leukemia virus infection in Ontario dairy herds. Prev. Vet. Med. 31:211-221.

Sordillo, L. M., C. R. Hicks, and G. M. Pighetti. 1994. Altered interleukin-2 production by lymphocyte populations from bovine leukemia virus-infected cattle. Proc. Soc. Exp. Biol. Med. 207:268-273.

Sorge, U. S., K. Lissemore, R. Cantin, and D. F. Kelton. 2011. Short communication: Milk ELISA status for bovine leukosis virus infection is not associated with milk production in dairy cows. J. Dairy Sci. 94:5062-5064.
Stata. 2013. ci-Confidence intervals for means, proportions, and counts. Pages 262-273 in Stata Base Reference Manual. StataCorp LP, College Station, TX.

Stone, D. M., A. J. Hof, and W. C. Davis. 1995. Up-regulation of IL-2 receptor alpha and MHC class II expression on lymphocyte subpopulations from bovine leukemia virus infected lymphocytotic cows. Vet. Immunol. Immunopathol. 48:65-76.

Stone, D. M., L. K. Norton, J. C. Chambers, and W. J. Meek. 2000. CD4 T lymphocyte activation in BLV-induced persistent B lymphocytosis in cattle. Clin. Immunol. 96:280-288.

Tiwari, A.. J. A. Vanleeuwen, I. R. Dohoo, G. P. Keefe, J. P. Haddad, R. Tremblay, H. M. Scott, and T. Whiting. 2007. Production effects of pathogens causing bovine leukosis, bovine viral diarrhea, paratuberculosis, and neosporosis. J. Dairy Sci. 90:659-669.

Trainin, Z., J. Brenner, R. Meirom, and H. Ungar-Waron. 1996. Detrimental effect of bovine leukemia virus (BLV) on the immunological state of cattle. Vet. Immunol. Immunopathol. 54:293-302.

Trono, K. G., D. M. Perez-Filgueira, S. Duffy, M. V. Borca, and C. Carrillo. 2001. Seroprevalence of bovine leukemia virus in dairy cattle in Argentina: Comparison of sensitivity and specificity of different detection methods. Vet. Microbiol. 83:235-248.

Walsh, R. B., D. F. Kelton, S. K. Hietala, and T. F. Duffield. 2013. Evaluation of enzyme-linked immunosorbent assays performed on milk and serum samples for detection of neosporosis and leukosis in lactating dairy cows. Can. Vet. J. 54:347-352.

Werling, D., C. J. Howard, E. Niederer, O. C. Straub, A. Saalmuller, and W. Langhans. 1998. Analysis of the phenotype and phagocytic activity of monocytes/macrophages from cattle infected with the bovine leukaemia virus. Vet. Immunol. Immunopathol. 62:185-195. 